\title{
Streptomyces lacticiproducens sp. nov., a lactic acid-producing streptomycete isolated from the rhizosphere of tomato plants
}

\author{
Correspondence \\ Hong-Hui Zhu \\ zhuhonghui66@yahoo.com.cn
}

\author{
Hong-Hui Zhu, ${ }^{1}$ Qing Yao, ${ }^{2}$ Song-Zhen Yang, ${ }^{1}$ Zhi-Kun Li ${ }^{1}$ and Jun Guo ${ }^{1}$ \\ ${ }^{1}$ Guangdong Provincial Microbial Culture Collection and Application Key Laboratory, Guangdong \\ Institute of Microbiology, Guangzhou, Guangdong 510070, PR China \\ ${ }^{2}$ South China Agricultural University, Guangzhou, Guangdong 510642, PR China
}

\begin{abstract}
A novel actinomycete, designated strain $\mathrm{GIMN} 4.001^{\top}$, was isolated from the rhizosphere of tomato plants grown in Guangzhou, China. The strain produced greyish white aerial mycelia, lactic acid and a large quantity of double diamond-shaped crystals on potato dextrose agar and yeast extract-malt extract agar. The colour of the substrate mycelium was not sensitive to $\mathrm{pH}$. Microscopic observations revealed that strain GIMN4.001 ${ }^{\top}$ produced verticillate chains of cylindrical spores. Chemotaxonomic data confirmed that strain GIMN4.001 ${ }^{\top}$ belonged to the genus Streptomyces. Melanin pigments were not produced. No antibacterial activity was observed against Escherichia coli, Pseudomonas aeruginosa, Bacillus subtilis or Candida albicans, but inhibitory activity was observed against Penicillium citrinum. 16S rRNA gene sequence analysis revealed that strain GIMN4.001 ${ }^{\top}$ was related most closely to Streptomyces morookaense ATCC $19166^{\top}$ (98.9\% similarity) and Streptomyces lavenduligriseus ATCC $13306^{\top}(98.7 \%)$. Levels of DNA-DNA relatedness between strain GIMN4.001 ${ }^{\top}$ and the type strains of these species were low (14-20\%). Furthermore, strain GIMN4.001 ${ }^{\top}$ could be differentiated from $S$. morookaense, $S$. lavenduligriseus and other closely related species of the genus Streptomyces based on morphological, physiological and biochemical characteristics. On the basis of its physiological and molecular properties, strain GIMN4.001 ${ }^{\top}$ is considered to represent a novel species of the genus Streptomyces, for which the name Streptomyces lacticiproducens sp. nov. is proposed. The type strain is GIMN4.001 ${ }^{\top}$ (=CCTCC $\mathrm{M} 208214^{\top}=$ NRRL B- $24800^{\top}$ ).
\end{abstract}

Members of the genus Streptomyces are ubiquitous, can be isolated easily on simple laboratory media, have broad metabolic abilities and can produce antibiotics, enzymes, enzyme inhibitors and pharmacologically active agents. They have thus been utilized in various fields, especially in the food and pharmaceutical industries (Bérdy, 2005). A novel strain of the genus Streptomyces, designated GIMN4.001 ${ }^{\mathrm{T}}$, was isolated from the rhizosphere of tomato plants grown in Guangzhou, China, in July 2008, by inoculating samples onto potato dextrose agar (Atlas, 2004) and incubating for 5-7 days at $28{ }^{\circ} \mathrm{C}$. The strain was observed to produce large quantities of double diamondshaped crystals on potato dextrose agar and yeast extractmalt extract agar (ISP 2).

\section{Abbreviation: DAP, diaminopimelic acid.}

The GenBank/EMBL/DDBJ accession number for the 16S rRNA gene sequence of strain GIMN4.001 ${ }^{\top}$ is GQ184344.

A supplementary figure is available with the online version of this paper.
International Streptomyces Project (ISP) media were prepared according to the methods of Shirling \& Gottlieb (1966). Morphological and physiological characteristics were determined as recommended by Williams et al. (1989), and morphological observations of spores and mycelia were made by light microscopy (DM RAR; Leica) as well as scanning electron microscopy (Philips FEI-XL30 and Hitachi S-3000N). Physiological tests were performed at $28{ }^{\circ} \mathrm{C}$ unless indicated otherwise. Melibiose, glucose, sucrose, D-fructose, xylose, D-galactose, arabinose, inositol and D-mannitol were tested as sole carbon source at concentrations of $0.1 \%(\mathrm{w} / \mathrm{v})$ and were filter-sterilized. Colour determination was referenced against Kornerup \& Wanscher (1978).

Analysis of the isomer of diaminopimelic acid (DAP) and the whole-cell sugar composition followed the procedure described by Hasegawa et al. (1983) with the exception that dried cells were used instead of colonies from agar plates. Fatty acid methyl esters were prepared by the trimethyl sulphonium hydroxide method (Butte, 1983) and were 
analysed by GC (6890; Hewlett Packard) by using the Microbial Identification software package (Sasser, 1990). The base composition of the genomic DNA of strain GIMN4.001 ${ }^{\mathrm{T}}$ was determined in $0.1 \times$ SSC according to the method of Mandel \& Marmur (1968). Genomic DNA was extracted (Cui et al., 2001) and the 16S rRNA gene sequence was amplified by PCR by using universal bacterial 16S rRNA gene primers. The forward primer F27 (5'AGAGTTTGATCCTGGCTCAG- $3^{\prime}$ ) and reverse primer 1522R ( $5^{\prime}$-AAGGAGGTGATCCAGCCGCA-3') were adapted from primers $\mathrm{pA}$ and $\mathrm{pH}$ of Edwards et al. (1989). The $16 \mathrm{~S}$ rRNA gene was sequenced with an automated capillary DNA sequencing system (ABI 3730) and a BigDye Terminator cycle sequencing kit. DNA relatedness studies were performed according to the fluorometric microdilution plate method (Ezaki et al., 1988; Sawabe et al., 1998).

Strain GIMN4.001 ${ }^{\mathrm{T}}$ grew well on ISP 2, inorganic saltsstarch agar (ISP 4) and potato dextrose agar. It exhibited moderate growth on glycerol-asparagine agar (ISP 5) and glucose-asparagine agar, poor growth on Gause's synthetic agar media (Atlas, 1993), and no growth on oatmeal agar (ISP 3) or starch agar media. Diffusible pigments were not observed on any of the various different media (Table 1). Double diamond-shaped crystals were produced on various agar media (see Supplementary Fig. S1, available in IJSEM Online), but were not observed in liquid media.

Morphological features of strain GIMN4.001 ${ }^{\mathrm{T}}$ were observed on ISP 2, ISP 4 and ISP 5 media after incubation for 2 weeks at $28{ }^{\circ} \mathrm{C}$. The novel strain exhibited morphological characteristics typical of the genus Streptomyces. Microscopy revealed a branched mycelium with verticils. The aerial mycelium produced verticillate chains of spores that were cylindrical and smooth (see Supplementary Fig. S2).

Chemotaxonomic analysis showed that the cell wall contained LL-DAP, typical of cell wall type I (Lechevalier \& Lechevalier, 1970), and whole-cell hydrolysates contained mannose, ribose and galactose. Fatty acid analysis showed that strain GIMN4.001 ${ }^{\mathrm{T}}$ contained straight-chain, and iso- and anteiso-branched components: anteiso- $\mathrm{C}_{15: 0}$ $(38.70 \%)$, iso- $\mathrm{C}_{16: 0}(12.55 \%)$, anteiso- $\mathrm{C}_{17: 0}(11.63 \%)$, iso- $\mathrm{C}_{15: 0}(9.75 \%), \mathrm{C}_{16: 0}(8.54 \%)$, iso- $\mathrm{C}_{14: 0}$ (4.64\%), iso- $\mathrm{C}_{17: 0}(2.85 \%)$ and cyclo $\mathrm{C}_{17: 0}(2.25 \%)$. The $\mathrm{G}+\mathrm{C}$ content of the genomic DNA of strain GIMN4.001 ${ }^{\mathrm{T}}$ was $70.91 \mathrm{~mol} \%$.

The almost-complete 16S rRNA gene sequence was determined for strain GIMN4.001 ${ }^{\mathrm{T}}$. Searches of the GenBank database with this sequence via the BLAST program (Altschul et al., 1997) showed its similarity to many species of the genus Streptomyces. Strain GIMN4.001 ${ }^{\mathrm{T}}$ showed $98.88 \%$ similarity (over 1408 bases) to the 16S rRNA gene sequence of Streptomyces morookaense NBRC $13416^{\mathrm{T}}, 98.67 \%$ similarity (over 1406 bases) to that of Streptomyces lavenduligriseus ATCC $13306^{\mathrm{T}}$ and less than $98 \%$ similarity to those of the type strains of other species of the genus Streptomyces.

A phylogenetic tree of $16 \mathrm{~S}$ rRNA gene sequences of members of the genus Streptomyces was constructed by using the neighbour-joining method of Saitou \& Nei (1987) with CLUSTAL W (version 1.81; Thompson et al., 1994) and MEGA (version 3.1; Kumar et al., 2001) (Fig. 1). For the neighbour-joining analysis, a distance matrix was calculated according to Kimura's two-parameter correction model. This tree shows the close phylogenetic association between strain GIMN4.001 ${ }^{\mathrm{T}}$ and recognized members of the genus Streptomyces.

The morphological and physiological characteristics of strain GIMN4.001 ${ }^{\mathrm{T}}$, for example cell-wall type, whole-cell sugar pattern and fatty acid profile, were consistent with those of members of the genus Streptomyces. Strain GIMN4.001 ${ }^{\mathrm{T}}$ produced lactic acid (determined by GCMS), a large quantity of double diamond-shaped crystals, greyish brown substrate mycelium and a greyish white spore mass of cylindrical spores in verticillate chains. Melanin was not produced on tyrosine agar (ISP 7). Comparison of the cultural characteristics of strain GIMN4.001 ${ }^{\mathrm{T}}$ and its closest phylogenetic neighbours (Table 2), however, revealed significant differences.

S. morookaense was unable to grow on ISP 2, ISP 3, ISP 4 or ISP 5 media and did not produce double diamond-shaped crystals; S. lavenduligriseus differed from the novel strain in that melanin pigments were produced on ISP 7. Despite

Table 1. Cultural characteristics of strain GIMN4.001 ${ }^{\top}$ on various media

ISP media (Shirling \& Gottlieb, 1966) are described in the text. No growth occurred on ISP 3 medium. The colour of mycelium was compared according to Kornerup \& Wanscher (1978).

\begin{tabular}{|lcccc|}
\hline Media & Growth & Sporulation & & \multicolumn{2}{c|}{ Colour of: } \\
\cline { 3 - 5 } & & & Aerial mycelium & Substrate mycelium \\
\hline ISP 2 & Good & Moderate & Greyish brown & Yellowish white \\
ISP 4 & Good & Moderate & Greyish yellow & Greenish yellow \\
ISP 5 & Moderate & Moderate & Greyish white & Greenish brown \\
Glucose-asparagine agar & Moderate & Moderate & White & Yellow \\
Gause's synthetic agar & Poor & Moderate & Yellowish white & Greyish yellow \\
Potato dextrose agar & Good & Grey-white & Greyish white & Ghite \\
\hline
\end{tabular}




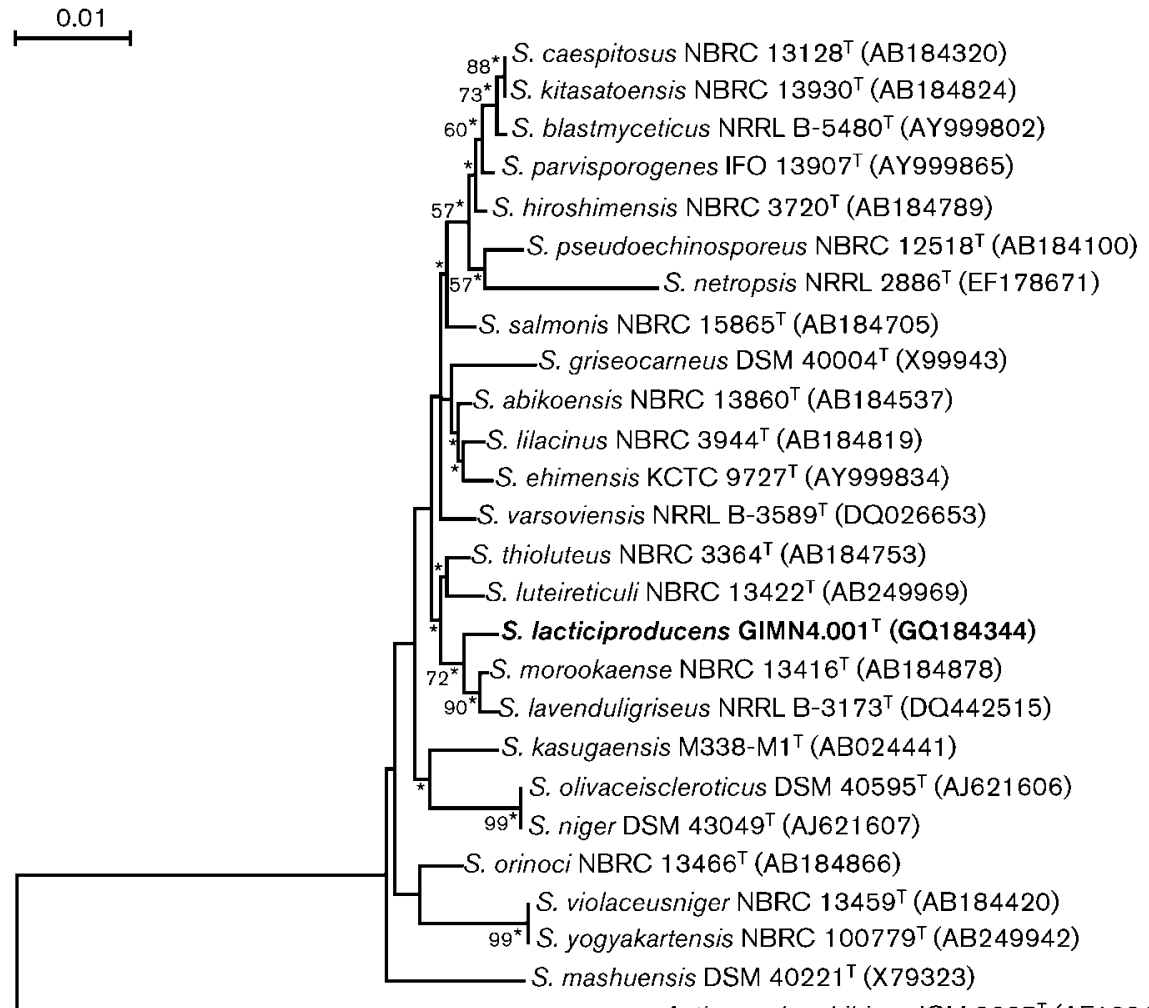

88* S. caespitosus NBRC $13128^{\top}$ (AB184320)

$73^{\star}$ S. kitasatoensis NBRC $13930^{\top}$ (AB184824)

$60^{*}$ LS. blastmyceticus NRRL B-5480 (AY999802)

* S. parvisporogenes IFO $13907^{\top}$ (AY999865)

$7^{\star}$ LS. hiroshimensis NBRC $3720^{\top}$ (AB184789)

-S. salmonis NBRC $15865^{\top}$ (AB184705)

S. griseocarneus DSM 40004 ${ }^{\top}$ (X99943)

S. abikoensis NBRC $13860^{\top}$ (AB184537)

S. lilacinus NBRC 3944 ${ }^{\top}$ (AB184819)

S. varsoviensis NRRL B-3589 ${ }^{\top}$ (DO026653)

S. thioluteus NBRC $3364^{\top}(\mathrm{AB} 184753)$

S. Iuteireticuli NBRC $13422^{\prime}(A B 249960)$

S. morookaense NBRC $13416^{\top}$ (AB184878)

S. lavenduligriseus NRRL B-3173 (DQ442515)

kasugaensis $\mathrm{M} 338-\mathrm{M}^{\top}{ }^{\top}$ (AB024441)

S. olivaceiscleroticus DSM 40595 (AJ621606)

S. niger DSM 43049 (AJ621607)

S. violaceusniger NBRC $13459^{\top}$ (AB184420)

S. mashuensis DSM $40221^{\top}$ (X79323)

Actinomadura hibisca JCM $9627^{\top}$ (AF163115)

Fig. 1. Unrooted neighbour-joining phylogenetic tree constructed from Streptomyces $16 \mathrm{~S}$ rRNA gene sequences. The 16S rRNA gene sequence of strain GIMN4.001 ${ }^{\top}$ was aligned with all sequences for members of the genus Streptomyces available in GenBank and a relevant subset of this alignment is shown. Actinomadura hibisca JCM $9627^{\top}$ was used as the outgroup. Bootstrap values (expressed as percentages of 1000 replications) of $>50 \%$ are given at nodes. The minimum-evolution and maximum-parsimony methods were also used for tree construction. Branches marked with an asterisk were conserved in all three methods. Bar, 0.01 substitutions per nucleotide position.

Table 2. Cultural characteristics of strain $\mathrm{GIMN} 4.001^{\top}$ and its closest phylogenetic relatives

Taxa: 1, GIMN4.001 ${ }^{\mathrm{T}}$; 2, S. morookaense; 3, S. lavenduligriseus. Data for reference species were taken from Hatano et al. (2003) and Shirling \& Gottlieb (1972). All taxa were negative production of diffusible pigment and for growth on sucrose as the sole carbon source. All taxa had smooth spore surfaces, gave a positive result for milk coagulation and were positive for growth on D-fructose, glucose and inositol as the sole carbon source. + , Positive; -, negative; w, weakly positive; ND, not determined.

\begin{tabular}{|lccc|}
\hline Characteristic & $\mathbf{1}$ & $\mathbf{2}$ & $\mathbf{3}$ \\
\hline Colony colour on ISP 2 & Greyish white & Pale yellow-green & Greyish yellow \\
Spore shape & Cylindrical & Oval or long round & Oval \\
Spore chain morphology & Verticillate & Verticillate & Rectiflexibiles to retinaculiaperti \\
Milk peptonization & - & - & + \\
Starch hydrolysis & - & ND & - \\
$\mathrm{H}_{2}$ S production & - & - & + \\
Melanin & - & - & + \\
Nitrate reduction & + & - & W \\
Growth on sole carbon source & & + & + \\
Arabinose & + & + & ND \\
D-Galactose & - & - & + \\
D-Mannitol & - & - & + \\
Melibiose & + & + & + \\
Xylose & + & & + \\
\hline
\end{tabular}


the high level of 16S rRNA gene sequence similarity between strain GIMN4.001 ${ }^{\mathrm{T}}$ and the type strains of $S$. morookaense and S. lavenduligriseus, they showed different morphological characteristics, cultural characteristics and carbon-utilization patterns (Table 2). Levels of DNA-DNA relatedness between strain GIMN4.001 ${ }^{\mathrm{T}}$ and S. morookaense ATCC $19166^{\mathrm{T}}$ and S. lavenduligriseus ATCC $13306^{\mathrm{T}}$ were 14.43 and $20.0 \%$, respectively, values well below the $70 \%$ threshold proposed by Wayne et al. (1987) for species delineation. Thus, DNA-DNA hybridization studies confirmed that strain GIMN4.001 ${ }^{\mathrm{T}}$ represented a novel species.

Other species of the genus Streptomyces showing $>98 \%$ $16 \mathrm{~S}$ rRNA gene sequence similarity to GIMN4.001 ${ }^{\mathrm{T}}$ had significant differences when grown on ISP media. For example, Streptomyces luteireticuli differed based on the production of yellowish and greenish yellow pigment on ISP media 2, 3, 4 and 5 (Hatano et al., 2003), and Streptomyces thioluteus differed in that aerial mycelium was not produced on these media (Shirling \& Gottlieb, 1972).

These results support the classification of strain GIMN4.001 ${ }^{\mathrm{T}}$ as representing a novel species of the genus Streptomyces, for which the name Streptomyces lacticiproducens sp. nov. is proposed.

\section{Description of Streptomyces lacticiproducens sp. nov.}

Streptomyces lacticiproducens (lac.ti.ci.pro'du.cens. N.L. n. acidum lacticum lactic acid; L. part. adj. producens producing; N.L. part. adj. lacticiproducens producing lactic acid).

Aerobic, Gram-positive, catalase-positive actinomycete that forms a yellowish white aerial mycelium and greyish brown substrate mycelium. Verticillate chains of cylindrical smooth-surfaced spores are produced. Diffusible pigments are not produced. Melanin pigments are not produced on ISP 7. Very good growth occurs on ISP 2, ISP 4 and potato dextrose agar; moderate growth on ISP 5 and glucoseasparagine agar; poor growth on Gause's synthetic agar media; no growth on ISP 3 or starch agar media. The substrate mycelium is greyish brown on ISP 2, greenish yellow on ISP 4 and ISP 5, yellow on glucose-asparagine agar, yellowish white on Gause's synthetic agar and greyish yellow on potato dextrose agar. The cell wall contains LLDAP (cell wall type I). No inhibitory activity is observed against Escherichia coli ATCC 25922, Pseudomonas aeruginosa ATCC 6538, Bacillus subtilis ATCC 6633 or Candida albicans ATCC 10231, but inhibitory activity is observed against Penicillium citrinum AS3.2788. Melibiose, glucose, D-fructose, xylose, inositol and arabinose are utilized as sole carbon source. Negative for production of $\mathrm{H}_{2} \mathrm{~S}$.

The type strain, GIMN4.001 ${ }^{\mathrm{T}} \quad\left(=\mathrm{CCTCC} \mathrm{M} 208214^{\mathrm{T}}=\right.$ NRRL B- $24800^{\mathrm{T}}$ ), was isolated from the rhizosphere of tomato plants grown in Guangzhou, China. The DNA G + C content of the type strain is $70.91 \mathrm{~mol} \%$

\section{Acknowledgements}

This work was supported by the National Natural Science Foundation of China, PR China (Project no. 30770067), International S\&T Cooperation Program of China (Project no. 2008DFA31560) and Guangdong Ministry of Science and Technology, PR China (Project no. 2009B050300003).

\section{References}

Altschul, S. F., Madden, T. L., Schaffer, A. A., Zhang, J., Zhang, Z., Miller, W. \& Lipman, D. J. (1997). Gapped BLAST and PSI-BLAST: a new generation of protein database search programs. Nucleic Acids Res 25, 3389-3402.

Atlas, R. M. (1993). Handbook of Microbiological Media. Edited by L. C. Parks. Boca Raton, FL: CRC Press.

Atlas, R. M. (2004). Handbook of Microbiological Media, 3rd edn. Boca Raton, FL: CRC Press.

Bérdy, J. (2005). Bioactive microbial metabolites, a personal view. J Antibiot (Tokyo) 58, 1-26.

Butte, W. (1983). Rapid method for the determination of fatty acid profiles from fats and oils using trimethylsulphonium hydroxide for transesterification. J Chromatogr A 261, 142-145.

Cui, X. L., Mao, P. H., Zeng, M., Li, W. J., Zhang, L. P., Xu, L. H. \& Jiang, C. L. (2001). Streptimonospora salina gen. nov., sp. nov., a new member of the family Nocardiopsaceae. Int J Syst Evol Microbiol 51, 357-363.

Edwards, U., Rogall, T., Blocker, H., Emde, M. \& Böttger, E. C. (1989). Isolation and direct complete nucleotide determination of entire genes. Characterization of a gene coding for $16 \mathrm{~S}$ ribosomal RNA. Nucleic Acids Res 17, 7843-7853.

Ezaki, T., Hashimoto, Y., Takeuchi, N., Yamamoto, H., Liu, S.-L., Miura, H., Matsui, K. \& Yabuuchi, E. (1988). Simple genetic method to identify viridans group streptococci by colorimetric dot hybridization and fluorometric hybridization in microdilution wells. J Clin Microbiol 26, 1708-1713.

Hasegawa, T., Takizawa, M. \& Tanida, S. (1983). A rapid analysis for chemical grouping of aerobic actinomycetes. J Gen Appl Microbiol 29, 319-322.

Hatano, K., Nishii, T. \& Kasai, H. (2003). Taxonomic re-evaluation of whorl-forming Streptomyces (formerly Streptoverticillium) species by using phenotypes, DNA-DNA hybridization and sequences of gyrB, and proposal of Streptomyces luteireticuli (ex Katoh and Arai 1957) corrig., sp. nov., nom. rev. Int J Syst Evol Microbiol 53, 1519 1529.

Kornerup, A. \& Wanscher, J. H. (1978). Methuen Handbook of Colour. London: Eyre Methuen.

Kumar, S., Tamura, K., Jakobsen, I. B. \& Nei, M. (2001). MEGA2: molecular evolutionary genetics analysis software. Arizona State University, Tempe, AZ, USA. http://www.megasoftware.net

Lechevalier, H. A. \& Lechevalier, M. P. (1970). A critical evaluation of the genera of aerobic actinomycetes. In The Actinomycetales, pp. 393405. Edited by H. Prauser. Jena: VEB Gustav Fischer.

Mandel, M. \& Marmur, J. (1968). Use of ultraviolet absorbancetemperature profile for determining the guanine plus cytosine content of DNA. Methods Enzymol 12B, 195-206.

Saitou, N. \& Nei, M. (1987). The neighbor-joining method: a new method for reconstructing phylogenetic trees. Mol Biol Evol 4, 406425.

Sasser, M. (1990). Identification of bacteria by gas chromatography of cellular fatty acids, MIDI Technical Note 101. Newark, DE: MIDI Inc. 
Sawabe, T., Makino, H., Tatsumi, M., Nakano, K., Tajima, K., Iqbal, M. M., Yumoto, L., Ezura, Y. \& Christen, R. (1998). Pseudomoalteromonas bacteriolytica sp. nov., a marine bacterium that is the causative agent of red spot disease of Laminaria japonica. Int J Syst Bacteriol 48, 769774 .

Shirling, E. B. \& Gottlieb, D. (1966). Methods for characterization of Streptomyces species. Int J Syst Bacteriol 16, 313-340.

Shirling, E. B. \& Gottlieb, D. (1972). Cooperative description of type strains of Streptomyces. V. Additional descriptions. Int J Syst Bacteriol 22, 265-394.

Staneck, J. L. \& Roberts, G. D. (1974). Simplified approach to identification of aerobic actinomycetes by thin-layer chromatography. Appl Microbiol 28, 226-231.

Thompson, J. D., Higgins, D. G. \& Gibson, T. J. (1994). CLUSTAL W: improving the sensitivity of progressive multiple sequence alignment through sequence weighting, position-specific gap penalties and weight matrix choice. Nucleic Acids Res 22, 4673-4680.

Wayne, L. G., Brenner, D. J., Colwell, R. R., Grimont, P. A. D., Kandler, O., Krichevsky, M. I., Moore, L. H., Moore, W. E. C., Murray, R. G. E. \& other authors (1987). International Committee on Systematic Bacteriology. Report of the ad hoc committee on reconciliation of approaches to bacterial systematics. Int J Syst Bacteriol 37, 463-464.

Williams, S. T., Goodfellow, M., Alderson, G., Wellington, E. M. H., Sneath, P. H. A. \& Sackin, M. J. (1983). Numerical classification of Streptomyces and related genera. J Gen Microbiol 129, 1743-1813.

Williams, S. T., Goodfellow, M. \& Alderson, G. (1989). Genus Streptomyces Waksman and Henrici 1943, 339 ${ }^{\mathrm{AL}}$. In Bergey's Manual of Systematic Bacteriology, vol. 4, pp. 2452-2492. Edited by S. T. Williams, M. E. Sharpe \& J. G. Holt. Baltimore: Williams \& Wilkins. 